\title{
Macrofauna of Laufuti Stream, Taú, American Samoa, and the Role of Physiography in Its Zonation ${ }^{1}$
}

\author{
Robert P. Cook ${ }^{2}$
}

\begin{abstract}
Laufuti Stream, on the island of Taú, American Samoa, is a complex interrupted perennial stream, consisting of three accessible sections, lower Laufuti (perennial), middle Laufuti (intermittent), and upper Laufuti (perennial), and the inaccessible falls zone, a series of four sheer, intermittent waterfalls separating lower Laufuti from middle Laufuti. The macrofauna consists primarily of amphidromous species that are relatively common and widespread in the tropical Pacific. However, in comparison with stream communities on $\mathrm{Tu}-$ tuila, Laufuti is unusual. Its shrimp community is more diverse and abundant, dominated by Macrobrachium latimanus, a species neither widespread nor abundant on Tutuila. It also supports a relatively diverse, alien-free freshwater fish community of six species representing three families, Gobiidae, Eleotridae, and Anguillidae, including Anguilla megastoma, a species of limited occurrence on Tutuila. The fish community of Laufuti is similar to that of other tropical $\mathrm{Pa}$ cific high-island streams in terms of dominant families, but zonation of macrofauna differs. There are no euryhaline fish species, and only Anguilla megastoma occurs above the falls zone. There are seven species of shrimps in lower Laufuti, but only Macrobrachium lar and M. latimanus occur above the falls zone. The severe dispersal barrier represented by the falls zone plus the absence of estuarine conditions, both products of the islands' geologic history, have produced a pattern of species distributions unlike that of most other tropical Pacific high islands.
\end{abstract}

Although the U.S. Territory of American Samoa contains many freshwater streams, studies of them are few. Most work on the Territory's streams has been directed toward stream flow (Matsuoka 1978, Wong 1996), groundwater quantity and quality (Bentley 1975, Izuka 1996, 1997), or surface water quality (M\&E Pacific, Inc. 1979). Surveys that include both biological (other than bacteria) and physical/chemical data are even fewer. They include two surveys of gastropods on Tutuila (Starmühlner 1993, Haynes 1990) and the more extensive American Sa-

${ }^{1}$ Manuscript accepted 1 April 2003.

2 National Park of American Samoa, Pago Pago, American Samoa 96799. Current address: National Park Service, 99 Marconi Site Road, Wellfleet, Massachusetts 02667 (E-mail: Robert_Cook@nps.gov).

Pacific Science (2004), vol. 58, no. 1:7-21

(C) 2004 by University of Hawai'i Press

All rights reserved moa Water Resources Study (Burger and Maciolek 1981, U.S. Army Corps of Engineers 1981). The American Samoa Water Resources Study collected data on fish, macroinvertebrates, and stream chemistry from 37 streams on Tutuila, providing an important baseline for monitoring changes in Tutuila streams, as well as a point of reference for evaluating streams elsewhere in American Samoa.

Laufuti Stream is a prominent feature on the southern coast of Taú Island (Figure 1), within the Taú Unit of the National Park of American Samoa. Taú is the remnant of a constructional dome that collapsed, forming a caldera on the island's south side. The caldera has only a northern rim and to the south is a valley that slopes downward, extending more than $2400 \mathrm{~m}$ below sea level (Stice and McCoy 1968). Major faulting produced the $425-\mathrm{m}$ escarpment that extends up to the island's summit, Lata Mountain, forming the northern boundary of the bench or down- 


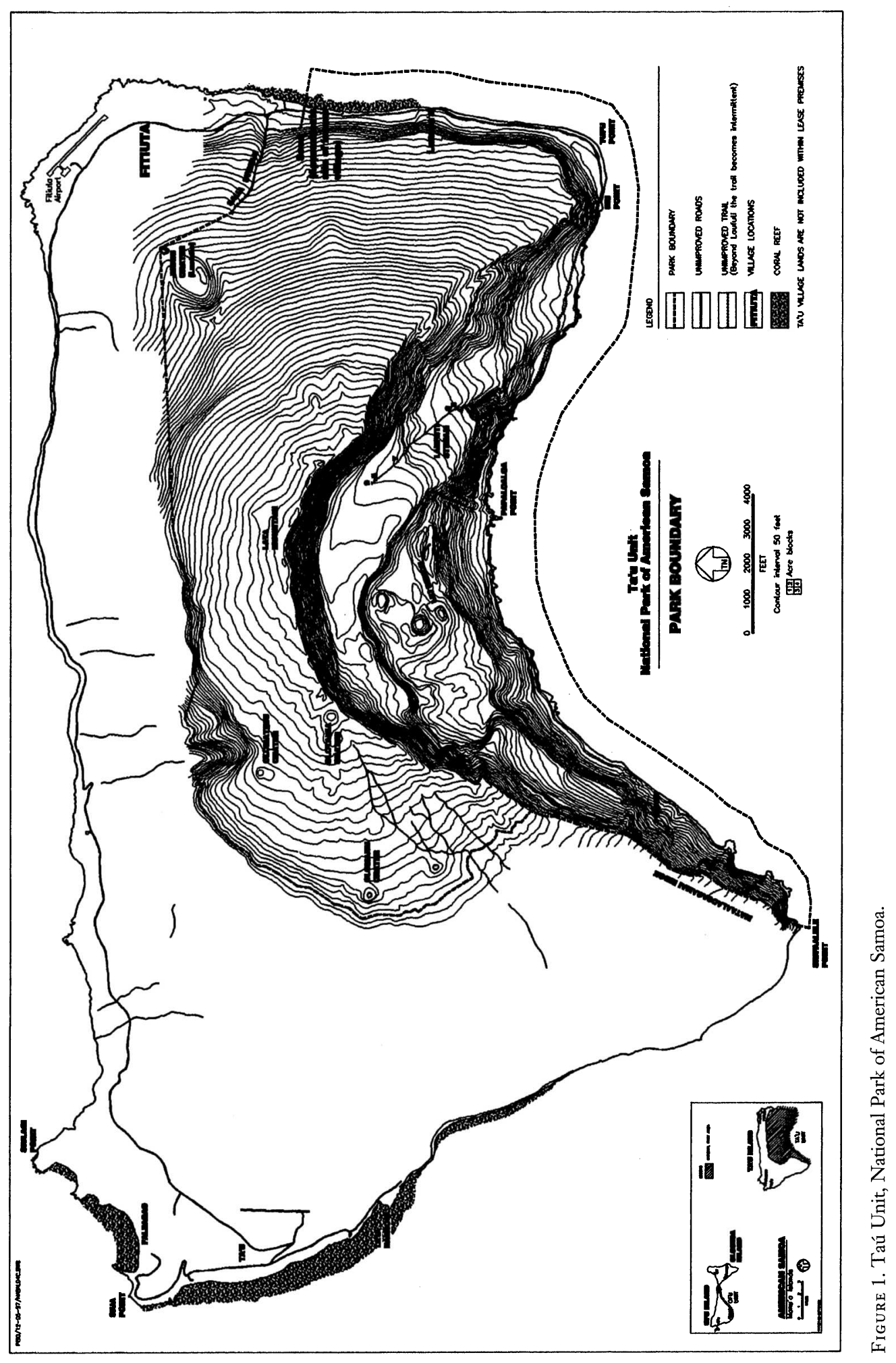


faulted block that Laufuti Stream flows across. This bench, referred to as Afuatai by Stice and McCoy (1968), is one of two within the collapsed caldera. Laufuti flows across Afuatai, a comparatively flat feature that rises in a northwesterly direction from Aufotu Cove on the south up to $550+\mathrm{m}$. It is bounded on the north by the fault escarpment below Lata Mountain and on the south by fault escarpments leading down to the coast and Ele'elesa or Liu Bench.

In addition to major faults, Stice and McCoy (1968) mapped a number of lesser faults. One extends across the stream's valley at 425 $\mathrm{m}$ elevation, separating upper from middle Laufuti. A second extends from 60 to $240 \mathrm{~m}$ elevation and angles across the stream valley. This fault, plus erosion through a complex of hundreds of dikes from sea level to $240 \mathrm{~m}$ elevation at the mouth of Laufuti (Stice and McCoy 1968), has created the cascades referred to here as the falls zone.
In the course of conducting a baseline inventory of Laufuti's physical, chemical, and biological conditions for the U.S. National Park Service (Cook 2001), data on macrofauna were collected. These data provide an opportunity for comparisons with streams on nearby Tutuila Island and other tropical $\mathrm{Pa}-$ cific high islands, and to analyze faunal distribution and zonation vis-à-vis physiography and geologic history.

\section{MATERIALS AND METHODS}

\section{Survey Sites and Dates of Sampling}

For the survey the stream was divided into four sections, separated by sheer cliffs that are waterfalls during periods of stream flow (Figure 2). Only three sections, lower Laufuti, middle Laufuti, and upper Laufuti, were accessible. The fourth, the falls zone, is a series of four sheer waterfalls that begin at $37 \mathrm{~m}$

Laufuti Stream Profile

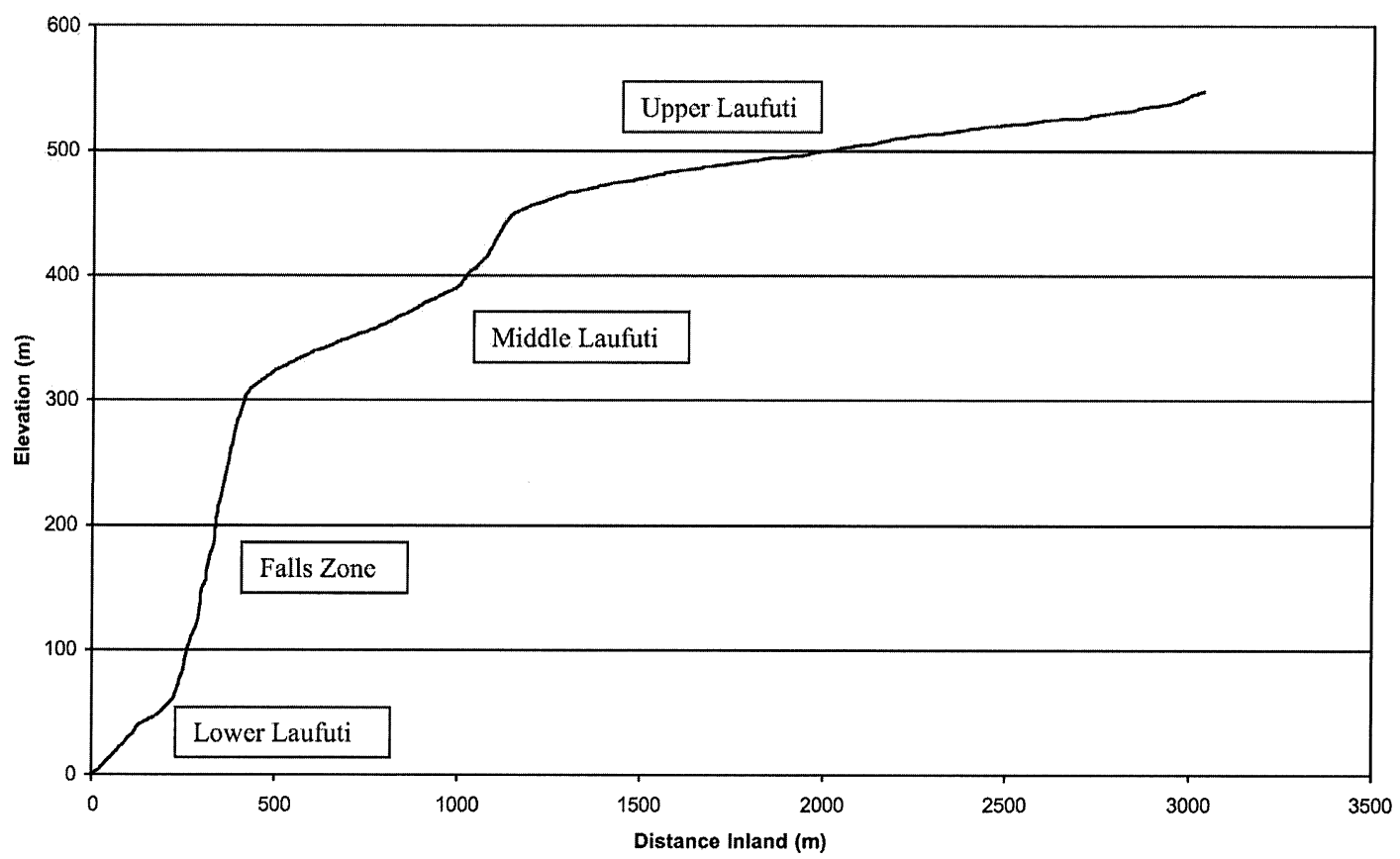

Figure 2. Profile of Laufuti Stream, Taú, showing the four sections referred to in text. 
elevation and rise to $263 \mathrm{~m}$. The falls zone separates lower Laufuti, which is accessed from the coast, from the rest of Laufuti Stream. The survey was conducted in three sampling periods: 19-21 November 1996 and 25-26 April 1997 (lower Laufuti) and 8-12 July 1997 (middle and upper Laufuti). A total of nine stations ranging in elevation from 2 to $467 \mathrm{~m}$ was sampled (Figure 3). Elevation of sampling stations and physiographic features was determined using an altimeter (Thommen Digital Altitronic), accurate to $10 \mathrm{~m}$. Features of sampling stations are summarized in Table 1.

\section{Physical Description of Sites}

Lower Laufuti (sites 1-3) is a perennial, spring-fed stream flowing through a highly dissected bedrock channel. The stream flows through a narrow, steep canyon with vertical walls up to $100 \mathrm{~m}$ above the streambed. Stream habitats alternate between riffles, runs, pools, and cascades. Substrate is predominantly boulder and cobble. The upper end of lower Laufuti is defined by the base of the "first waterfall," elevation $37 \mathrm{~m}$.

The falls zone consists of a series of four sheer waterfalls, ranging in height from 14 to $131 \mathrm{~m}$. There are pools of standing water at the base of the first and second waterfalls. Based on numerous visits between 1996 and 1998 , there is always a slight flow of water over the first waterfall, but only once was water observed flowing over the second. The third (and largest) waterfall was never observed with water flowing over it. The pool at the base of the fourth waterfall was dry on the four occasions it was observed from above.

Middle Laufuti (sites 4-6) is intermittent. Though no flow was observed, scouring of bedrock and dry plunge pools indicate periods of very heavy flow, probably as flash floods. It is a dissected bedrock channel, with channel depth varying from 1 to $10 \mathrm{~m}$. Substrate is a mix of bedrock and boulders, though dry pools contain cobble and gravel. From 263 to $312 \mathrm{~m}$ elevation it has a high gradient, dominated by boulders and bedrock, with large dry pools and cascades up to $10-15 \mathrm{~m}$ high. From 312 to $346 \mathrm{~m}$ elevation, it is flatter, more uniform in its ascent, and the streambed has more bedrock and less boulders. Most of middle Laufuti's pools are from 312 to $346 \mathrm{~m}$ elevation. From $346 \mathrm{~m}$ to the dead end at $383 \mathrm{~m}$ elevation, middle Laufuti again has a high gradient, with large boulders and deep dry pools below dry waterfalls 5-10 m high.

Upper Laufuti (sites 7-9) begins atop a waterfall at $433 \mathrm{~m}$ elevation. It is relatively flat, with very little incision into the bedrock. The streambed surface reflects more the influence of volcanic activity than of postvolcanic water flow. Features of volcanic flow, the horizontal pāhoehoe flows of Afuatai (Stice and McCoy 1968), are readily observable. From 433 to $460 \mathrm{~m}$ there is no flowing water. The streambed consists of numerous small (usually less than $1 \mathrm{~m}$ diam.), shallow (maximum $0.3 \mathrm{~m}$ deep) pools. From 460 to $503 \mathrm{~m}$ elevation, Laufuti is a slow-flowing perennial stream, $1-2 \mathrm{~m}$ wide and 0.1 to $0.5 \mathrm{~m}$ deep. Exploration of upper Laufuti was halted at $503 \mathrm{~m}$ elevation. Here the stream was flowing, $1 \mathrm{~m}$ wide, $0.5 \mathrm{~m}$ deep, and overgrown with dense shrubs. Though the topographic map for Taú (U.S. Geological Survey 1963) shows no water flow in Laufuti above $363 \mathrm{~m}$, these observations suggest that it is another kilometer to the stream's source.

\section{Biological Sampling}

On lower Laufuti, biota were initially sampled with funnel traps (Gee's Minnow Trap G-40) baited with canned sardines. These yielded relatively few captures, in spite of the observed presence of many fishes and crustaceans. To facilitate comparison with inventories conducted on Tutuila (U.S. Army Corps of Engineers 1981), electroshocking (Smith Root Backpack Electroshocker model 15-C) was conducted on 20-m-long sections at sites 1-3 (Figure 3). The length of each section was electroshocked for 159 to $229 \mathrm{sec}$ (mean, $199 \mathrm{sec}$ ). Two persons standing downstream with long-handled dip nets collected stunned specimens.

In electroshock sampling of lower Laufuti, capture rates were influenced by stream velocity. Pools and other slow-moving sites 


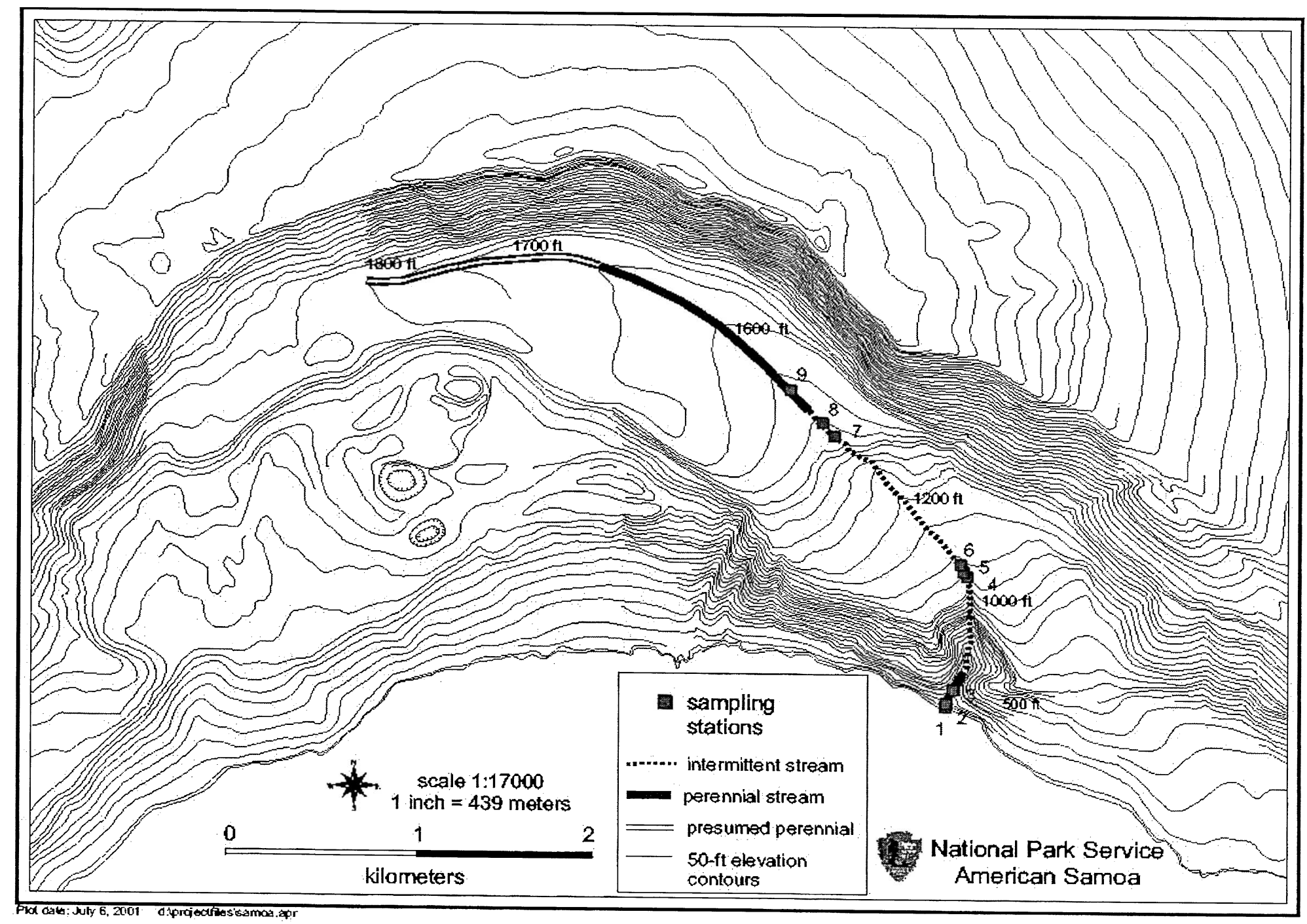

FIGURE 3. Laufuti Stream, Taú, showing sampling locations and sections of perennial and intermittent flow. 
TABLE 1

Physical Features of Sampling Stations on Laufuti Stream, Taú

\begin{tabular}{llrllcccc}
\hline \hline Site & Section & $\begin{array}{c}\text { Elev. } \\
(\mathrm{m})\end{array}$ & $\begin{array}{c}\text { Streambed } \\
\text { Feature }\end{array}$ & \multicolumn{1}{c}{ Substrate } & $\begin{array}{c}\text { Length } \\
(\mathrm{m})\end{array}$ & $\begin{array}{c}\text { Width } \\
(\mathrm{m})\end{array}$ & $\begin{array}{c}\text { Depth } \\
(\mathrm{m})\end{array}$ & $\begin{array}{c}\text { Discharge } \\
\left(\mathrm{m}^{3} / \mathrm{sec}\right)\end{array}$ \\
\hline 1 & Lower & 2 & Riffle & Boulder & 20 & 2.2 & 0.4 & 0.0569 \\
2 & Lower & 15 & Riffle/run & Boulder-cobble & 20 & 2.5 & 0.8 & 0.0190 \\
3 & Lower & 34 & Pool-flowing & Boulder-cobble & 20 & 2.5 & 0.2 & 0.0020 \\
4 & Middle & 317 & Pool-standing & Bedrock-boulder & 9 & 5 & 0.5 & \\
5 & Middle & 322 & Pool-standing & Bedrock-boulder & 10 & 5 & 0.5 & \\
6 & Middle & 328 & Pool-standing & Boulder-cobble & 8 & 8 & 0.7 & \\
7 & Upper & 448 & Pool-standing & Bedrock & 6 & 3 & 0.2 & \\
8 & Upper & 455 & Pool-standing & Bedrock & 10 & 3 & 0.3 & 0.0028 \\
9 & Upper & 467 & Pool-flowing & Bedrock & 16 & 0.4 & 0.2 & 0.0028 \\
\hline
\end{tabular}

Note: Stream flow is perennial at sites 1-3 and 9, and intermittent at sites 4-8. Discharge measured 9 July 1997 (from Cook [2001]).

produced few captures, though many individuals could be seen reacting to the shocker. Rather than being carried downstream into nets, stunned animals dropped down between rocks and went unsampled. Because middle and upper Laufuti contained only nonflowing and slowly flowing pools, sampling with an electroshocker was not attempted.

Middle and upper Laufuti were sampled with small funnel traps only. On middle Laufuti, sites 4-6 were isolated, nonflowing pools. On upper Laufuti, sampling sites 7-8 were also isolated pools, whereas site 9 was a slowly flowing pool. Sampling effort at each site consisted of three funnel traps, each baited with half a tin of sardines packed in oil. Traps were checked and rebaited 2 days later and specimens collected. Traps were rechecked and removed 1 day later. In addition, snails and eels were hand-collected opportunistically. Three eels (Anguilla megastoma) were collected from upper and middle Laufuti. Digestive tracts of these three, plus one collected in Amalau Valley, Tutuila (elevation $320 \mathrm{~m}$ ), were dissected and analyzed for food habits. At site 9, density of Melanoides tuberculata was estimated with a $0.0929-\mathrm{m}^{2}\left(1-\mathrm{ft}^{2}\right)$ randomly placed quadrat.

Biological specimens were fixed in $10 \%$ formalin for $24 \mathrm{hr}$, soaked in water for $48 \mathrm{hr}$, and stored in 50\% ethanol. Freshwater shrimps were identified using keys developed for American Samoa (Devaney 1981) and confirmed at the Bishop Museum, Hono- lulu (David Muir and Lucius Eldredge, pers. comm., 1998), where representative specimens were deposited. Snails were also identified at the Bishop Museum (Robert $\mathrm{H}$. Cowie, pers. comm., 1997). Fish specimen identification was confirmed at the U.S. National Museum of Natural History, anguillids by David G. Smith and all others by Lynne Parenti (L. Parenti, pers. comm., 1998). Nomenclature of fishes used in this report and synonyms were provided by David Smith and Lynne Parenti, U.S. National Museum of Natural History (L. Parenti, pers. comm., 1998). A representative sample of each species was accessioned into the NMNH collection (accession no. 419049).

\section{RESULTS}

Two gastropod, seven crustacean, and six fish species were collected (Table 2). For both crustaceans and fishes, species richness was greatest in lower Laufuti. Only the two freshwater shrimps Macrobrachium lar and $M$. latimanus were recorded throughout the length of the stream.

Electroshocking in lower Laufuti yielded seven species of freshwater shrimps representing two families and five species of fishes representing three families (Table 3). The most abundant palaemonid shrimp was $M$. lar and the most abundant atyid was Caridina weberi. The fish fauna was dominated by members of the family Gobiidae (three spe- 
TABLE 2

Distribution of Macrofauna in Laufuti Stream Based on All Methods of Detecting Presence

\begin{tabular}{|c|c|c|c|}
\hline Species & $\begin{array}{l}\text { Lower } \\
\text { Laufuti }\end{array}$ & $\begin{array}{l}\text { Middle } \\
\text { Laufuti }\end{array}$ & $\begin{array}{l}\text { Upper } \\
\text { Laufuti }\end{array}$ \\
\hline \multicolumn{4}{|l|}{ Gastropods } \\
\hline $\begin{array}{l}\text { Neritina variegata } \\
\text { Melanoides tuberculata }\end{array}$ & $X$ & $X$ & $X$ \\
\hline \multicolumn{4}{|l|}{ Shrimps } \\
\hline Macrobrachium lar & X & $\mathrm{X}$ & $X$ \\
\hline M. latimanus & $X$ & $\mathrm{X}$ & $X$ \\
\hline M. australe & $X$ & & \\
\hline M. birtimanus & $X$ & & \\
\hline Atya serrata & $X$ & & \\
\hline A. spinipes & $\mathrm{X}$ & & \\
\hline Caridina weberi & $\mathrm{X}$ & & \\
\hline \multicolumn{4}{|l|}{ Bony fishes } \\
\hline Anguilla marmorata ${ }^{a}$ & $\mathrm{X}$ & & \\
\hline A. megastoma $a^{b}$ & & $\mathrm{X}$ & $\mathrm{X}$ \\
\hline Eleotris fusca & $X$ & & \\
\hline Sicyopterus pugnans & $X$ & & \\
\hline S. micrurus ${ }^{c}$ & $\mathrm{X}$ & & \\
\hline Stiphodon elegans & $\mathrm{X}$ & & \\
\hline
\end{tabular}

${ }^{a}$ Reported by U.S. Army Corps of Engineers (1981) as $A$. mauritania.

${ }^{b}$ Reported by U.S. Army Corps of Engineers (1981) as $A$. celebensis.

${ }^{c}$ Reported by U.S. Army Corps of Engineers (1981) as $S$. taeniurus.

cies), with the most abundant being Sicyopterus micrurus. Site 1 had the highest species richness for both crustaceans and fishes, with all but one species recorded in the entire survey represented at that station.

Trapping yielded three species of freshwater shrimps and two species of fishes in lower Laufuti. In middle and upper Laufuti, only the shrimp $M$. latimanus was caught, in spite of $M$. lar and Anguilla megastoma being readily observed. Based on catch per trap night, densities of shrimps in middle and upper Laufuti were two orders of magnitude greater than that in lower Laufuti, with $M$. latimanus dominating the shrimp community in those sections (Table 4).

The two species of gastropods recorded were Neritina variegata, found only in lower Laufuti, and Melanoides tuberculata. Melanoides tuberculata was rare in middle Laufuti and common to abundant in upper Laufuti. At site 9 , they were very conspicuous, reaching a density estimated at $538 / \mathrm{m}^{2}$.
Digestive tract contents of Anguilla megastoma were crustacean remains (identifiable as shrimp or simply as crustacean) (75\% occurrence, six items), various insects $(50 \%$ occurrence, three items), and the snail $M . t u$ berculata ( $25 \%$ occurrence, three items).

\section{DISCUSSION}

\section{Gastropods}

The two species of snails found in Laufuti are widely distributed among tropical Pacific islands (Haynes 1990). Neritina variegata is native to Oceania and the Indo-Pacific (Haynes 1988, Cowie 1998), its widespread distribution likely due to the amphidromous reproduction of neritids (Cowie 1998, Hodges and Allendorf 1998). This survey extends its known range in Samoa to include Taú. $\mathrm{Mel}$ anoides tuberculata is likely Asian or African in origin (Cowie 1998) and it has been introduced throughout the region though human activity (Haynes 1990).

The distribution of these two species within Laufuti Stream corresponds closely to accounts from the Samoan islands of Upolu and Tutuila (Starmühlner 1993) and the Fiji Islands (Haynes 1990). Neritina variegata, restricted to lower Laufuti, is a species found in the lower reaches of fast-flowing streams, whereas $M$. tuberculata is generally found in pools and low-velocity habitats that have sandy/muddy bottoms and rich plant materials. Although its distribution can range from sea level to $500 \mathrm{~m}$ and may overlap with that of $N$. variegata, typical habitat for $M$. tuberculata occurred principally on upper Laufuti, where it was most abundant. There it reached an estimated density of 538 individuals per square meter at site 9. Starmühlner (1993) noted maxima of 100-500 individuals per square meter.

The two species of gastropods found in Laufuti contrasts with 13 species found on Tutuila (Haynes 1990). This is consistent with Haynes (1990), who found that gastropod species richness of tropical Pacific islands is primarily a function of water area, which is also a significant correlate of island area and stream length. Taú is much smaller 
TABLE 3

Number of Individuals Collected by Electroshocking on Lower Laufuti and, for Entire Stream, by Trapping and All Methods Combined

\begin{tabular}{|c|c|c|c|c|c|c|}
\hline \multirow[b]{2}{*}{ Species } & \multicolumn{3}{|c|}{ Electroshock } & \multirow{2}{*}{$\begin{array}{c}\text { Total } \\
\text { Electroshock }\end{array}$} & \multirow{2}{*}{$\begin{array}{c}\text { Total } \\
\text { Trapping }\end{array}$} & \multirow{2}{*}{$\begin{array}{c}\text { All } \\
\text { Methods }\end{array}$} \\
\hline & Site 1 & Site 2 & Site 3 & & & \\
\hline \multicolumn{7}{|l|}{ Shrimps } \\
\hline Macrobrachium lar & 27 & 16 & 9 & 52 & 7 & 59 \\
\hline M. latimanus & 9 & 10 & 3 & 22 & 1,071 & 1,093 \\
\hline M. australe & 5 & 4 & & 9 & 1 & 10 \\
\hline M. birtimanus & 8 & 2 & & 10 & & 10 \\
\hline Atya serrata & 116 & 12 & 0 & 128 & & 128 \\
\hline A. spinipes & 12 & 248 & 5 & 265 & & 265 \\
\hline Caridina weberi & 42 & 233 & 238 & 513 & & 513 \\
\hline Total individual shrimps & 219 & 525 & 255 & 999 & 1,079 & 2,078 \\
\hline Species richness & 7 & 7 & 4 & 7 & 3 & 7 \\
\hline Shannon diversity index $\left(\mathrm{H}_{2}^{\prime}\right)$ & 2.03 & 1.5 & 0.45 & 2.81 & 0.07 & 2.3 \\
\hline \multicolumn{7}{|l|}{ Bony fishes } \\
\hline Anguilla marmorata & 2 & 2 & & 4 & 1 & 5 \\
\hline A. megastoma & & & & & & 3 \\
\hline Eleotris fusca & 3 & 1 & 3 & 7 & 2 & 9 \\
\hline Sicyopterus pugnans & 3 & & & 3 & & 3 \\
\hline S. micrurus & 52 & 3 & 2 & 57 & & 57 \\
\hline Stiphodon elegans & 4 & & & 4 & & 4 \\
\hline Total individual fishes & 64 & 6 & 5 & 75 & 3 & 81 \\
\hline Species richness & 5 & 3 & 2 & 5 & 2 & 6 \\
\hline Shannon diversity index $\left(\mathrm{H}_{2}^{\prime}\right)$ & 1.06 & 1.46 & 0.97 & 1.26 & 0.92 & 1.52 \\
\hline Electroshocker time (sec) & 159 & 209 & 229 & & & \\
\hline
\end{tabular}

than Tutuila (39 versus $140 \mathrm{~km}^{2}$ ), with far fewer streams, especially permanent ones.

\section{Crustaceans}

The shrimp community of Laufuti Stream is composed of fairly common, widespread species. The seven species occur widely throughout the Indo-Pacific region (Devaney 1981). All were recently (1979-1980) recorded on Tutuila, with three (M. lar, $M$. australe, and C. weberi) described as very common and widespread on Tutuila (U.S. Army Corps of Engineers 1981). Yet, although the shrimp species occurring in Laufuti are not unusual individually, as a community they differ from those found on Tutuila.

The shrimp community of Laufuti Stream is one of the most diverse in American Samoa. It has a greater number of species than $89 \%$ of the 37 streams surveyed on Tutuila (U.S. Army Corps of Engineers 1981). Only one stream on Tutuila surpassed Laufuti in species richness, and three equaled it (Table 5). For a single sampling station, Laufuti site 1 surpassed $95 \%$ of 71 stations on Tutuila (U.S. Army Corps of Engineers 1981). The highest diversity values $\left(\mathrm{H}_{2}^{\prime}\right)$ reported for stream crustaceans on Tutuila was 1.86 for a single station and 1.45 for a stream with multiple sampling stations (U.S. Army Corps of Engineers 1981). Most (14 of 24, 68\%) Tutuila streams had values for crustacean $\mathrm{H}_{2}^{\prime}$ below 1.00 (U.S. Army Corps of Engineers 1981). Comparable values for Laufuti Stream are 2.03 for a single electroshock site, 2.81 for all three electroshock sites combined, and 2.30 for all methods combined (Table 3). Thus the shrimp community of Laufuti Stream ranks as one of the most diverse recorded in American Samoa.

The most unusual aspect of Laufuti's shrimp community is the prominence of $M$. latimanus. This species is not widespread on 
TABLE 4

Numbers of Individuals by Species and Catch per Trap Night (in Parentheses) Collected with Funnel Traps in Laufuti Stream

\begin{tabular}{|c|c|c|c|c|c|c|c|c|c|}
\hline \multirow[b]{3}{*}{ Species } & \multirow[b]{3}{*}{ No. Trap Nights } & Lower Laufuti & Site 4 & Site 5 & Site 6 & Site 7 & Site 8 & Site 9 & Total \\
\hline & & $\begin{array}{c}\text { Nov. } 1996+ \\
\text { Apr. } 1997\end{array}$ & $\begin{array}{c}8-11 \\
\text { July } 1998\end{array}$ & $\begin{array}{c}8-11 \\
\text { July } 1998\end{array}$ & $\begin{array}{c}8-11 \\
\text { July } 1998\end{array}$ & $\begin{array}{c}8-11 \\
\text { July } 1998\end{array}$ & $\begin{array}{c}8-11 \\
\text { July } 1998\end{array}$ & $\begin{array}{c}8-11 \\
\text { July } 1998\end{array}$ & \\
\hline & & 9 & 9 & 9 & 9 & 9 & 5 & 5 & 55 \\
\hline \multicolumn{10}{|c|}{ Gastropods } \\
\hline \multicolumn{2}{|c|}{$\begin{array}{l}\text { Neritina variegata } \\
\text { Melanoides tuberculata }\end{array}$} & Observed & & & & Observed & $1(0.2)$ & $9(1.8)$ & $10(0.18)$ \\
\hline \multicolumn{2}{|c|}{ M. latimanus } & $\begin{array}{l}2(0.22) \\
1(0.11)\end{array}$ & $185(20.6)$ & $157(17.4)$ & $379(42.11)$ & $75(8.3)$ & $143(28.6)$ & $132(26.4)$ & $1,071(19.47)$ \\
\hline \multicolumn{10}{|c|}{ Bony fishes } \\
\hline \multicolumn{2}{|c|}{$\begin{array}{l}\text { Anguilla marmorata } \\
\text { A. megastoma }\end{array}$} & $\begin{array}{l}1(0.11) \\
2(0.22)\end{array}$ & Observed $^{a}$ & Observed & Observed & Observed & Observed & & $1(0.02)$ \\
\hline
\end{tabular}


TABLE 5

Shrimp Community of Laufuti Stream Compared with Those of the Most Species-Rich Streams on Tutuila Reported on by U.S. Army Corps of Engineers (1981)

\begin{tabular}{lccccc}
\hline \hline & \multicolumn{5}{c}{ Entire Stream } \\
\cline { 2 - 6 } Species & Laufuti & Auvai & Papa & Vaitele & Soonapule \\
\hline Atya serrata & $\mathrm{X}$ & $\mathrm{X}$ & & $\mathrm{X}$ & $\mathrm{X}$ \\
A. spinipes & $\mathrm{X}$ & $\mathrm{X}$ & $\mathrm{X}$ & $\mathrm{X}$ & $\mathrm{X}$ \\
Caridina weberi & $\mathrm{X}$ & $\mathrm{X}$ & $\mathrm{X}$ & $\mathrm{X}$ & $\mathrm{X}$ \\
C. serratirostris & & $\mathrm{X}$ & $\mathrm{X}$ & $\mathrm{X}$ & \\
C. nilotica & $\mathrm{X}$ & $\mathrm{X}$ & $\mathrm{X}$ & $\mathrm{X}$ & $\mathrm{X}$ \\
Macrobracbium lar & $\mathrm{X}$ & $\mathrm{X}$ & $\mathrm{X}$ & $\mathrm{X}$ & $\mathrm{X}$ \\
M. latimanus & $\mathrm{X}$ & $\mathrm{X}$ & $\mathrm{X}$ & $\mathrm{X}$ & $\mathrm{X}$ \\
M. australe & 7 & 7 & 8 & 7 & 7 \\
M. birtimanus & 2.81 & 1.45 & 1.39 & 0.87 & 1.28 \\
$\quad$ Species richness & 3 & 2 & 4 & 3 & 1 \\
$\quad$ Species diversity $\left(\mathrm{H}_{2}^{\prime}\right)$ & No. of sampling stations & & & &
\end{tabular}

Tutuila. It was recorded as occasional at 8 of 71 stations and 8 of 37 streams (U.S. Army Corps of Engineers 1981). In Laufuti, $M$. latimanus was common at two of three electroshock sites and abundant at the trapping sites above the falls zone. In spite of possible trapping bias for this species, it is clearly numerous in middle and upper Laufuti, a situation that is unusual in American Samoa.

The shrimp community of Laufuti is spatially variable, with seven species recorded in lower Laufuti and only two in middle and upper Laufuti. In addition, M. latimanus is spatially variable in abundance. Spatial variability in $M$. lar in a Hawaiian stream was noted by Timbol et al. (1989), who only recorded it at low elevations. Conversely, in Micronesia, Nelson et al. (1995, 1997) found Macrobrachium sp. and atyid shrimps to be more abundant at higher elevations, above a waterfall that acted as a barrier to a predator, Mountain Bass (Kublia rupestris). In that case, spatial variation in abundance was attributed to variation in predator effects rather than to physical features. In addition, barriers, through their effects on predator distribution, can also cause spatial variation in the age structure of a stream's atyid shrimp population (Leberer and Nelson 2001). In Laufuti, Kublia was absent, but eels (A. marmorata and $A$. megastoma), which feed heavily on shrimps (Marquet and Lamarque 1986, Leberer and Nelson 2001), provide predation pressure throughout. In Laufuti, it appears that some of the species occurring in lower Laufuti may be excluded from middle and upper Laufuti by either dispersal barriers (i.e., falls zone) or lack of habitat (i.e., lack of flowing water) rather than by distribution of predators. Based on trapping data (Table 4) the abundance of $M$. latimanus is much greater in middle and upper Laufuti than in lower Laufuti. Part of this may be due to shrimps being concentrated in standing pools as opposed to the flowing stream habitat of lower Laufuti. But even at sites 8 and 9, which were streamlike, the shrimps were abundant. Differences in abundance between lower Laufuti and middle/upper Laufuti are likely due to food availability. Organic matter (such as leaf detritus) is a major component of stream energy flow (U.S. Army Corps of Engineers 1981) and was observed to be much more abundant in the nonflowing pools and slow-flowing stream of middle/upper Laufuti than in the fast-moving lower Laufuti. Middle and upper Laufuti are more frequently under a forest canopy and presumably receive greater organic input. This factor, plus the tendency for organic matter to collect in standing pools, would lead to a greater food base for leaf shredders such as Macrobracbium 
sp. A similar relationship between shrimp abundance, leaf litter, and flow regime occurs on Guam (Ellis-Neill 1991).

\section{Fishes}

Similar to the shrimps, all six fish species recorded in Laufuti Stream (Table 2) are widespread through the Indo-Pacific region (Fowler 1928, 1931，1934，1949, Munro 1967). All were recently (1979-1980) recorded on Tutuila and four (A. marmorata, Eleotris fusca, S. micrurus, Stiphodon elegans) were described then as common and/or widespread on Tutuila, occurring in over $60 \%$ of streams sampled (U.S. Army Corps of Engineers 1981). Conversely, S. pugnans occurred in only $19 \%$ (7/37) of streams, and $A$. megastoma was recorded in only one stream. Thus the fish community of Laufuti Stream combines mostly common species with two that appear to be uncommon to rare in American Samoa.

Compared with streams on Tutuila, the fish community of Laufuti Stream is relatively diverse, with species richness that equals or exceeds that of $78 \%$ of Tutuila streams. For a single sampling station, Laufuti site 1 species richness exceeded that of $70 \%$ of the Tutuila stations (U.S. Army Corps of Engineers 1981). Diversity index $\left(\mathrm{H}_{2}^{\prime}\right)$ values for Laufuti Stream rank it as one of the most diverse stream fish communities in the Territory. The highest values of $\mathrm{H}_{2}^{\prime}$ reported for stream fishes on Tutuila by U.S. Army Corps of Engineers (1981) were 1.51 and 1.21 for a single station, and 1.17 for a stream with more than one sampling station. Only 4 of 24 (17\%) values for fish $\mathrm{H}_{2}^{\prime}$ reported by U.S. Army Corps of Engineers (1981) exceeded 1.00 . Comparable values obtained in this survey for Laufuti Stream are 1.46 for a single electroshock site, 1.26 for all three electroshock sites combined, and 1.52 for all methods combined (Table 3 ).

In comparing the fish community of Laufuti with those of Tutuila streams, there are three differences. First, none of the alien species reported for Tutuila is present. Second, Laufuti lacks the euryhaline species (e.g., Kublia sp.) that occur at low elevations in streams with low-gradient, tidally influenced mouths. Third, Laufuti lacks a number of freshwater gobies recorded from Tutuila by U.S. Army Corps of Engineers (1981). Wass (1984) noted that many gobies were habitat specific and of limited occurrence. This is likely a factor in their absence from Laufuti.

\section{Fish Community Structure}

Freshwater fish communities of Australia and the Pacific island region are relatively depauperate, due to the absence of the Ostariophysi, which account for almost $88 \%$ of the world's primary freshwater fishes (Darlington 1957, Powell and Powell 1999). Tropical Pacific islands tend to be even more depauperate, a function of insularity, island size, and distance from centers of origin (Powell and Powell 1999), coupled with the volcanic origin of most tropical Pacific islands. Young volcanic islands lack well-developed estuarine habitats, have low stream habitat diversity, and are characterized by highvelocity streams with many waterfalls. These conditions favor colonization by gobies, gudgeons, and eels (Gobiidae, Eleotridae, and Anguillidae, respectively), noted for their ability to climb or crawl (Moriarty 1978, Baker and Foster 1992). Although weathering leads to greater stream habitat diversity, the already established gobies and gudgeons are better positioned to exploit the new habitats. Through adaptation and speciation, they tend to occupy the majority of freshwater niches to the general exclusion of other families (Ryan 1991). Dominance of streams by gobies, gudgeons, and eels is well documented on many tropical Pacific islands (Bright and June 1981, Timbol et al. 1989, Ryan 1991, Balon and Bruton 1994, Nelson et al. 1997, Powell and Powell 1999), including Tutuila (U.S. Army Corps of Engineers 1981). Laufuti conforms to this pattern, with its six species of fishes limited to members of these three families.

The role of physiography in shaping tropical Pacific island stream fish communities is well documented (Timbol et al. 1989, Marquet and Galzin 1991, Polhemus et al. 1992, Marquet 1996, Pusey and Kenard 1996, Nelson et al. 1997, Powell and Powell 1999). Al- 
though details vary, the "model" stream has three zones. The lower zone begins with estuarine conditions and continues inland into the coastal lowlands. There follows a middle zone where gradient increases, and an upper zone, where stream gradient is even higher (Marquet and Galzin 1991, Polhemus et al. 1992, Pusey and Kennard 1996, Powell and Powell 1999). In general, species richness is greatest in the lower zone, due to the presence of euryhaline species. The middle and upper zones are dominated by the Gobiidae and Eleotridae (Balon and Bruton 1994, Powell and Powell 1999), though headwater reaches in Hawai'i lack fishes (Polhemus et al. 1992).

Physiography affects stream communities by influencing entry of species into streams and the extent of upstream penetration. Older islands have better-developed estuarine habitats, allowing euryhaline species to enter the lower zone and, in the case of genera such as Kublia, to penetrate inland (Polhemus et al. 1992, Balon and Bruton 1994, Nelson et al. 1997, Powell and Powell 1999). In contrast, geologically young islands are characterized by steep slopes, few estuaries, and a transition from fresh to seawater in a few meters, limiting the entry of euryhaline species (Ryan 1991). One-million-year-old Taveuni in Fiji is a graphic example (Ryan 1991), and Taú, age 0.1 million yr (McDougall 1985) is another. The "mouth" of Laufuti is a combination of surface flow across and seepage through a steep boulder and cobble field beach, $2 \mathrm{~m}$ above the tidal range. Laufuti's lack of an estuarine "mouth" prevents the entry of euryhaline species.

In many tropical Pacific island streams, waterfalls play an important role in zonation, serving to delineate stream sections and determine species' distributions. Waterfalls limit upstream penetration of many species and, through the attenuation of predation and/or competition, allow for increased dominance and biomass in the species occurring above the waterfall (Marquet and Lamarque 1986, Timbol et al. 1989, Marquet and Galzin 1991, Balon and Bruton 1994, Pusey and Kennard 1996, Nelson et al. 1997). On Bouganville Island, Papua New Guinea, where no mention is made of waterfalls, $A$. marmorata and Kublia occur throughout the three river zones (Powell and Powell 1999). In Pohnpei and Palau, Kublia is restricted to waters below major waterfalls, $A$. marmorata occurs above the waterfalls but does not penetrate into the headwaters, and species of Stiphodon and Sicyopus (including $S$. elegans) occur up into the headwaters (Nelson et al. 1995, 1997). On the Tatinga River of Anjouan, Comoro Archipelago, there are two waterfalls, each $15 \mathrm{~m}$ high. Kublia and E. fusca are limited to below the first fall, $A$. marmorata occurs up to the second waterfall, but only Sicyopterus lagocephalus is able to ascend the high-velocity waters of the upper waterfall (Balon and Bruton 1994).

Eels are capable of surmounting barriers such as waterfalls (Moriarty 1978), but the observations on Anjouan suggest that, for $A$. marmorata, these abilities are limited (Balon and Bruton 1994). In French Polynesia, $A$. marmorata is geographically widespread and occurs from lower to upper zone in many streams. However, they are excluded from the upper zone "when the waterfall that separates it from the middle zone is too high" (Marquet and Galzin 1991). Anguilla megastoma is not as widely distributed geographically nor within stream zones. It occurs in the middle and upper zones, sometimes with $A$. marmorata, but also above waterfalls, where $A$. marmorata is absent (Marquet and Lamarque 1986). A similar pattern of zonation occurs in New Caledonia (Marquet 1996) and in Laufuti Stream, with $A$. marmorata restricted by the falls zone to lower Laufuti and $A$. megastoma occurring in middle and upper Laufuti.

These patterns of in-stream zonation detail how species vary in their ability to surmount dispersal barriers and show that the community structure of stream zones varies depending on the type, location, and severity of barriers and the species available to be influenced. Among the species discussed, ability to surmount barriers increases as follows: Kublia sp., Stenogobius sp., E. fusca, A. marmorata, Stiphodon sp., Sicyopus sp., Sicyopterus sp., A. megastoma. Thus, stream fish communities exhibit zonation, but details vary for each 
stream and reflect the influence of geologic history on a stream's physiography. In the case of Laufuti Stream, the island's geologic history has created a stream lacking an estuarine connection, abruptly partitioned into zones by faulting. This limits the entry of species into the stream and restricts all but the most capable dispersers to the stream's lower reach, below the extreme barrier of the falls zone.

\section{Diet of Anguilla megastoma}

Diet of eels on tropical Pacific islands is opportunistic, with variation between species a function of prey availability. In addition, because of interstream variation in macrofauna distribution due to physiography, intraspecific variation in diet would also be expected. In Tahiti, the diet of $A$. megastoma was dominated by crustaceans (primarily Macrobrachium spp.), gobies, and mollusks (Marquet and Lamarque 1986). The diet of $A$. megastoma in American Samoa shows a similar opportunism, being dominated by crustaceans, devoid of fishes (because they occurred in the absence of other fishes), containing comparable amounts of mollusks, and including insects, a taxon not recorded in the diet of Tahitian A. megastoma (Marquet and Lamarque 1986).

\section{ACKNOWLEDGMENTS}

This work was made possible by the U.S. National Park Service, National Park of American Samoa, Christopher Stein, Superintendent. Field assistance was provided by Mino Fialua, Francis Huber, Dain Perry, David Vana-Miller and Don Tiernan. Assistance with specimen identification was provided by Robert Cowie, Lucius Eldredge, and David Muir of the Bishop Museum and by David Smith and Lynne Parenti, U.S. National Museum of Natural History. Preliminary drafts were improved by comments from Peter Craig, Mark Flora, John Portnoy, David Vana-Miller, and two anonymous reviewers. Map figures were created by Melia Lane-Kamahele and Mark Adams.

\section{Literature Cited}

Baker, J. A., and S. A. Foster. 1992. Estimating density and abundance of endemic fishes in Hawaiian streams. Division of Aquatic Resources, Hawai'i Department of Land and Natural Resources, Honolulu.

Balon, E. K., and M. N. Bruton. 1994. Fishes of the Tatinga River, Comoros, with comments on freshwater amphidromy in the goby Sicyopterus lagocephalus. Ichthyol. Explor. Freshwater 5 (1): 25-40.

Bentley, C. B. 1975. Ground-water resources of American Samoa with emphasis on the Tafuna-Leone Plain, Tutuila Island. U.S. Geol. Surv. Water Res. Invest. 75-29.

Bright, G. R., and J. A. June. 1981. Freshwater fishes of Palua, Caroline Islands. Micronesica 17:107-111.

Burger, I. L., and J. A. Maciolek. 1981. Map inventory of nonmarine aquatic resources of American Samoa with on-site biological annotations. Review draft. U.S. Fish and Wildlife Service, National Fisheries Research Center, Seattle, Washington. Available at University of Hawai'i, Pacific Collection.

Cook, R. P. 2001. An inventory of Laufuti stream, Taú, American Samoa. National Park Service, Water Res. Div., Fort Collins, Colorado. Tech. Rep. NPS/ NRWRD/NRTR-2001/290.

Cowie, R. H. 1998. Catalog of the nonmarine snails and slugs of the Samoan Islands. Bishop Mus. Bull. Zool. 3.

Darlington, P. J., Jr. 1957. Zoogeography: The geographical distribution of animals. Wiley \& Sons, New York.

Devaney, D. M. 1981. Identification of American Samoa freshwater crustaceans. Contract Report PODED-P-64-81, U.S. Army Corps of Engineers, Pacific Ocean Division, Honolulu, Hawai'i.

Ellis-Neill, L. 1991. Distribution and production dynamics of benthic invertebrates in a tropical stream on Guam. Micronesica 24 (2): 295.

Fowler, H. W. 1928. The fishes of Oceania. Mem. Bishop Mus. Vol. 10.

. 1931. The fishes of Oceania. Suppl. 1. Mem. Bishop Mus. Vol. 11, 5:313-381. 
1934. The fishes of Oceania. Suppl. 2. Mem. Bishop Mus. Vol. 11, 6:385460.

. 1949. The fishes of Oceania. Suppl. 3. Mem. Bishop Mus. Vol. 12, 2:37186.

Haynes, A. 1988. Notes on the stream neritids (Gastropoda: Prosobranchia) of Oceania. Micronesica 21:93-102.

. 1990. The numbers of freshwater gastropods on Pacific islands and the theory of island biogeography. Malacologia 31:237-248.

Hodges, M. H., and F. W. Allendorf. 1998. Population genetics and pattern of larval dispersal of the endemic Hawaiian freshwater amphidromous gastropod Neritina granosa (Prosobranchia: Neritidae). Pac. Sci. 52:237-249.

Izuka, S. K. 1996. Summary of ground-water and rainfall data for Tutuila and Aunuu Islands, American Samoa, for July 1984, through September 1995. U.S. Geol. Surv. Open File Rep. 96-116.

. 1997. Summary of ground-water and rainfall data for Tutuila and Aunuu Islands, American Samoa, for July 1985, through September 1996. U.S. Geol. Surv. Open File Rep. 97-654.

Leberer, T., and S. G. Nelson. 2001. Factors affecting the distribution of atyid shrimps in two tropical insular rivers. Pac. Sci. 55:389-398.

M\&E Pacific, Inc. 1979. Baseline water quality survey, American Samoa. Report for U.S. Army Corps of Engineers, Pacific Ocean Division, Honolulu, Hawai' $i$.

Marquet, G. 1996. The freshwater eels (Anguillidae) of New Caledonia: Taxonomy and distribution. Vie Milieu 46:65-71.

Marquet, G., and R. Galzin. 1991. The eels of French Polynesia: Taxonomy, distribution and biomass. La Mer 29:8-17.

Marquet, G., and P. Lamarque. 1986. Acquisitions recentes sur la biologie des anguilles de Tahiti et de Moorea (Polynesie Francaise): $A$. marmorata, $A$. megastoma, $A$. obscura. Vie Milieu 36:311-315.

Matsuoka, I. 1978. Flow characteristics of streams in Tutuila, American Samoa. U.S. Geol. Surv. Water Res. Invest. 78-103.
McDougall, I. 1985. Age and evolution of the volcanoes of Tutuila, American Samoa. Pac. Sci. 39:311-317.

Moriarty, C. 1978. Eels: A natural and unnatural history. Universe Books, New York.

Munro, I. S. R. 1967. The fishes of New Guinea. Department of Agriculture, Stock, and Fisheries, Port Moresby, New Guinea.

Nelson, S. G., B. D. Smith, J. E. Parham, B. Tibbatts, and F. A. Camacho. 1995. A survey of the streamfishes of the upper reaches of the Ngermeskang River, Palau, with recommendations for conservation and monitoring. Univ. Guam Mar. Lab. Tech. Rep. 100.

Nelson, S. G., J. E. Parham, R. B. Tibbatts, F. A. Camacho, T. Leberer, and B. D. Smith. 1997. Distributions and microhabitats of the amphidromous gobies in streams of Micronesia. Micronesica 30:8391.

Polhemus, D. A., D. Maciolek, and J. Ford. 1992. An ecosystem classification of inland waters for the tropical Pacific islands. Micronesica 25:155-173.

Powell, J. H., and R. E. Powell. 1999. The freshwater ichthyofauna of Bougainville Island, Papua New Guinea. Pac. Sci. 53: 346-356.

Pusey, B. J., and M. J. Kennard. 1996. Species richness and geographical variation in assemblage structure of the freshwater fish fauna of the wet Tropics region of northern Queensland. Mar. Freshwater Res. 47:563-573.

Ryan, P. A. 1991. The success of the Gobiidae in tropical Pacific insular streams. N. Z. J. Zool. 18:25-30.

Starmühlner, F. 1993. Ergebnisse der österreichischen Tonga-Samoa Expedition 1985 des Instituts für Zoologie der Universität Wien: Beiträge zur Kenntnis der Süß- und Brackwasser-Gastropoden der Tonga- und Samoa-Inseln (SW-Pazifik). Ann. Naturhist. Mus. Wien Ser. B Bot. Zool. 94/95: 217-306, pls. 1-11.

Stice, G., and F. McCoy. 1968. The geology of the Manua Islands, Samoa. Pac. Sci. $22: 427-457$. 
Timbol, A. S., M. H. Kido, and D. E. Heacock. 1989. A descriptive study of selected biological and physicochemical characteristics of Limahuli stream, Kauai, Hawaii. Hawai'i Stream Resource Center, University of Hawai'i (www2.hawaii.edu/hsrc/ home/timbolsv.htm).

U.S. Army Corps of Engineers. 1981. American Samoa stream inventory, island of Tutuila, American Samoa Water Resources Study. U.S. Army Corps of En- gineers, Pacific Ocean Division, Honolulu, Hawai'i.

U.S. Geological Survey. 1963. Topographic map. Manua Islands, American Samoa.

Wass, R. C. 1984. An annotated checklist of the fishes of Samoa. NOAA Tech. Rep. NMFS SSRF-781.

Wong, M. F. 1996. Analysis of streamflow characteristics for streams on the island of Tutuila, American Samoa. U.S. Geol. Surv. Water Res. Invest. 96-4185. 